\title{
Iskolai elsősegélynyújtás oktatás a Pécsi Tankerületi Központban - kihívások és lehetőségek
}

\author{
School-based first aid education in the Pécs School District Centre - \\ challenges and opportunities
}

Szerzők: Bánfai Bálint ${ }^{a} \bowtie$, Bánfai-Csonka Henriettaa ${ }^{a}$ Musch Jánosª , Derzsi-Horváth Martina ${ }^{b}$, Deutsch Krisztina ${ }^{a}$, Betlehem József ${ }^{a}$

a: Pécsi Tudományegyetem, Egészségtudományi Kar, Sürgősségi Ellátási és

Egészségpedagógiai Intézet, Pécs, b: Pécsi Tudományegyetem, Egészségtudományi Kar, Egészségtudományi Doktori Iskola, Pécs

Beküldve: 2020. 09.07.

doi: $\quad$ 10.24365/ef.v61i4.635

\begin{abstract}
Összefoglaló:
Bevezetés: Az iskolai keretek között megvalósuló elsősegélynyújtás oktatás megfelelő módszer lehet a cselekedni képes laikus elsősegélynyújtók számának növelésére. Kutatásunk célja volt felmérni a helyzetet a Pécsi Tankerületi Központ fenntartása alá tartozó általános- és középiskolákban.

Módszer: Kutatásunkat a Pécsi Tankerületi Központ intézményeiben végeztük. Az adatgyújtés saját szerkesztésű kérdőív segítségével történt 2019. március és június között. A kérdőív a következő kérdéscsoportokat tartalmazta: (1) szociodemográfiai jellemzők, (2) saját tapasztalatok és attitűd az elsősegélynyújtás oktatásával kapcsolatosan, (3) a jelenlegi helyzet, lehetőségek és nehézségek a munkahelyül szolgáló intézményben.

Eredmények: A kérdőívet 43 intézményből összesen 114 fő töltötte ki. Mindössze a kitöltők 32,5\%-a tudta, hogy a Nemzeti Alaptanterv tartalmazza az elsősegélynyújtást. A kitöltók 63,2\%-a gondolta úgy, hogy az elsősegélynyújtás oktatásnak kötelezőnek kellene lennie gyermekkorban. Az intézmények 12,3\%-ában zajlik rendszeresen elsősegélynyújtással kapcsolatos program, melyek 17,6\%-a valósul meg tanóra keretein belül. A megkérdezett pedagógusok 7\%-a oktat jelenleg elsősegélynyújtást, 16,7-uk szívesen végezné ezt a tevékenységet, 43,9\%-a ellátná ezt a feladatot, de csak ez irányú továbbképzés után. A kapott válaszok alapján a leggyakoribb gátló tényezők a következők voltak: időhiány, kevés elsősegélynyújtással és ennek oktatásával kapcsolatos tapasztalat, a tantervbe történő „nem illeszkedés”.
\end{abstract}

Következtetések: A megkérdezettek válaszaiból kapott eredmények lehetőséget teremthetnek beavatkozási pontok meghatározására, viszont a helyzet javítása érdekében tágabb értelmezés és több szektor együttmúködése szükséges, csak így érhető el valódi eredmény.

Kulcsszavak: elsősegélynyújtás; újraélesztés; köznevelés; oktatás; általános iskola

Summary:

Introduction: School-based first aid education can be an effective way to increase the number of lay first aid providers who are able to act. Our aim was to measure the current situation in primary- and secondary schools maintained by the School District Centre of Pécs, Hungary. 
Methods: The study was carried out in the schools of the Pécs School District Centre. Data were collected using a self-edited questionnaire between March and June 2019. The questionnaire contained the following question sets: (1) socio-demographic characteristics, (2) own experiences and attitudes about first aid education, (3) current situation, opportunities, and barriers in the schools.

Results: In total, 114 participants responded the questionnaire from 43 schools. Only $32.5 \%$ of respondents knew that the Hungarian National Core Curriculum includes first aid. In total, $63.2 \%$ of participants answered that first aid education should be compulsory in childhood. Only $12.3 \%$ of schools organized first aid programmes regularly, with only $17.6 \%$ of these programmes carried out as part of school classes. Seven percent of the teachers asked teaches first aid, $16.7 \%$ would like to teach it, and $43.9 \%$ would like to teach it only after having participated in a first aid training. The answers indicated the following most common barriers: lack of time, lack of experience in first aid and its education, 'no fit' into the curricula.

Conclusions: Based on the answers it is possible to determine the points of intervention However, a wider view and multi-sectoral co-operation would be necessary to obtain real results.

Keywords: first aid; resuscitation; public education; education; primary school

\section{BEVEZETÉS}

A gyors és szakszerű elsősegélynyújtás életet menthet. A laikusok által nyújtott elsősegély aránya és minősége sajnos világszerte nagyon alacsony, a legtöbb esetben $20 \%$ alatt marad. ${ }^{1,2,3}$ Rendszeres és megfelelő minőségú oktatással ez az arány javítható. ${ }^{4,5,6} \mathrm{Az}$ elsősegélynyújtás társadalmasításának egyik lehetséges módja a gyermekkorban elkezdett oktatás, hiszen ezzel a módszerrel a társadalom egy széles szegmense egyszerre válik elérhetővé. ${ }^{7}$ Ezzel kapcsolatban több hazai és nemzetközi szervezet kötelezővé tette a gyerekek számára az elsősegélynyújtás - és ezen belül is az újraélesztés - oktatását. ${ }^{8,9}$ Ennek leghatékonyabb módja az iskolai keretek között történő oktatás lehet, a tanterv részeként. ${ }^{10} \mathrm{~A}$ hazai helyzet javítása érdekében a World Health Organization (WHO) által is támogatott „Kids Save Lives"” program hazai adaptálását munkacsoportunk megkezdte, "Kids save lives in Hungary" elnevezéssel. ${ }^{11,12}$

Hazánkban a Nemzeti Alaptanterv (NAT) 1995 óta tartalmazza az elsősegélynyújtást. ${ }^{13}$ A megtartott programok $^{14,15}$ sikerei és hatékonysága ellenére eddig nem sikerült egységesen integrálni az elsősegélynyújtást a köznevelésbe. Az új NAT 2020. januárjában elérhetővé vált, mely részben tartalmazza a munkacsoportunk által korábban megfogalmazott javaslatokat az elsősegélynyújtás oktatás témakörében, ugyanakkor a valódi bevezetéshez további intézkedések lennének szükségesek. ${ }^{16,17}$ Nemzetközi kutatások eredményei alapján, a tantervbe történő beillesztés leggyakoribb gátló tényezői a nem elegendő idő, a pedagógusok képzettségének hiánya és az egységes szabályozások hiánya voltak. $18,19,20,21,22,23$ Hazai szinten bár elérhetők különböző forrásokból (pl. média) származó információk, objektív adatokat bemutató, tudományos igényességú kutatás ezidáig nem zajlott a témában.

Kutatásunk célja volt feltérképezni, hogy iskolai keretek között milyen arányban és formában valósul meg elsősegélynyújtás oktatással kapcsolatos tevékenység, illetve a megvalósulás hiányának milyen okai lehetnek . Ezen kívül általánosságban is szerettük volna felmérni az intézmények vezetőinek és az ott dolgozó pedagógusok véleményét a gyermekkori elsősegélynyújtás oktatással kapcsolatban. Hazánkban a köznevelési intézmények fenntartása a Klebelsberg Központ (KK) feladata, melyben az intézmények Tankerületi Központokba sorolva találhatók meg (összesen 70 tankerületi központba). Jelen kutatásunk célja a Pécsi Tankerületi Központhoz tartozó intézmények felmérése volt. 


\section{MÓDSZER}

Kutatásunk egy keresztmetszeti, feltáró, kvantitatív elemeket tartalmazó vizsgálat volt, melybe a Pécsi Tankerületi Központ intézményeinek vezetői és pedagógusai kerültek bevonásra. A résztvevőktől a köznevelés keretein belül megvalósuló elsősegélynyújtás oktatás jelenlegi helyzetével kapcsolatos véleményeket kívántuk felmérni. A Pécsi Tankerületi Központhoz összesen 70 intézmény tartozik (33 településen, 43 általános iskola, 7 gimnázium, 20 egyéb intézmény), az összesített tanulói létszám 2019-ben 17.354 fő volt, így kutatásunk eredményeinek ők lehetnek a jövőben a közvetett élvezői. ${ }^{24}$ Adatgyűjtési eszközként egy saját szerkesztésű kérdőívet alkalmaztunk, melynek kérdéseit munkacsoportunk állította össze. A kérdőív a következő kérdéscsoportokat tartalmazta: (1) szocio-demográfiai kérdések (14 kérdés); (2) gyermekkori elsősegélynyújtás oktatással kapcsolatos attitűd (8 kérdés); (3) jelenlegi elsősegélynyújtás oktatással kapcsolatos helyzetkép, ezzel kapcsolatos segítő és gátló tényezők (14 kérdés); (4) gyermekkori elsősegélynyújtás oktatással kapcsolatos általános vélemények (8 kérdés).

A kérdések nagyrészt zárt kérdésként voltak megfogalmazva, mely alól kivételt képezett az a néhány eset, ahol szöveges véleményt írhattak be a kitöltők („Egyéb” válaszlehetőségként). Ezen kívül több kérdésnél 6-fokozatú Likert-skálát alkalmaztunk. Ennek oka az volt, hogy - középérték hiányában a kitöltőknek mindenképpen el kelljen válaszaikkal mozdulniuk valamelyik irányba. Ezen kérdéseknél utólag bizonyos elemzések esetén a következőképpen csoportosítottuk a válaszokat: 1-3 = „inkább nem ért egyet” , 4-6 = „inkább egyetért”. A kérdőívet online formában (Google Ûrlapok) küldtük el a Pécsi Tankerületi Központnak, melynek igazgatójával a kutatás részleteit előzetesen egyeztettük. A Pécsi Tankerületi Központ hivatalos formában küldte el a kérdőívet az összes hozzá tartozó intézménynek. A kitöltésre az egyes intézmények vezetőit kértük meg, valamint minden intézményből olyan pedagógusokat kívántunk bevonni, akik korábban kapcsolatba kerültek már gyermekkori elsősegélynyújtás oktatással, illetve olyanokat is, akik még nem, azért hogy mindkét csoport képviseltethesse véleményét, ezáltal relevánsabb képet nyújtva a valós helyzetről.
Az iskolák vezetőjének, illetve a pedagógusoknak ugyanazt a kérdőívet kellett kitölteniük, az egyetlen különbség egy plusz kérdés volt a vezetők felé, melyben az iskolába járó gyermekek számát kellett megadniuk. A kérdőívek kitöltése 2019. március 1. és 2019. május 31. között történt meg, mely időintervallum alatt két alkalommal került emlékeztető kiküldésre azon potenciális résztvevő intézményeknek, akik képviselői addig még nem töltötték ki a kérdőívet.

A kutatási eszköz végső formájának kiküldése előtt egy szakértői csoport (pedagógusok, kutatásmódszertanban és statisztikában jártas szakemberek bevonásával) véleményezte a kérdőívet, mely során volt lehetőség az esetleges módosítások elvégzésére. Ugyancsak a végleges verzió elkészítését megelőzően a kérdőív kiküldésre került 5 fő pedagógusnak, akik kitöltötték és esetleges módosítási javaslatok, észrevételek megfogalmazására is volt lehetőségük.

\section{Statisztikai elemzés módja}

Az adatbázis elkészítése és az adatok elemzése Microsoft Excel és SPSS 24.0 szoftverekkel történt. A mintát leíró statisztikai mutatókkal jellemeztük (abszolút és relatív gyakoriság, átlag, szórás, minimum, maximum), az összefüggések és különbségek feltárása érdekében pedig matematikai statisztikai eljárásokat alkalmaztunk (Khi-négyzet-próba, illetve szükség esetén Fisher's-exact teszt, t-próba, ANOVA, korreláció-analízis). A kapott eredményeket 95\%-os konfidencia intervallum mellett, $p<0,05$ érték esetén tekintettük szignifikánsnak.

\section{Etikai engedély}

Kutatásunk elvégzését a Pécsi Tudományegyetem Klinikai Központ Regionális és Intézményi KutatásEtikai Bizottsága engedélyezte (Ügyiratszám: 7756 PTE 2019). A vizsgálat elkezdését megelőzően a Pécsi Tankerületi Központ igazgatója, valamint a Pécsi Tankerületi Központhoz tartozó intézmények vezetői és pedagógusai szóbeli, illetve írásos tájékoztatást kaptak, mely tartalmazta a kutatás céljára és lebonyolításának módjára vonatkozó információkat. 


\section{EREDMÉNYEK}

A felmérés során összesen 43 intézményből érkezett értékelhető válasz, mely 61,4\%-os válaszadási arányt jelent a Pécsi Tankerületi Központon belül. Minden kitöltőt figyelembe véve 114 kérdőív adatait dolgoztuk fel ( $\mathrm{N}=114)$.

A kitöltők szocio-demográfiai jellemzése és az elsősegélynyújtással való korábbi kapcsolat bemutatása

A minta összefoglaló jellemzése az 1. táblázatban látható.

Az egyes tényezőknél elsődlegesen a \%-os megoszlás került feltüntetésre, zárójelben pedig a részminta elemszáma látható. Az életkor és a munkában eltöltött idő esetében az átlag után a szórás is feltüntetésre került.

A kitöltők mindössze 6,1\%-a (7 fö) nem vett részt korábban semmilyen elsősegélynyújtással kapcsolatos képzésen, míg 93,9\%-uk igen, közöttük vannak olyanok is, akik több fórumon. A jogosítvány megszerzésével összefüggésben 78,9\% (84fő), korábbi tanulmányai során 35,1\% (38 fő), munkahelyén 33,3\% (36 fő) tanult elsősegélynyújtást, ezeken kívül csupán néhány esetben merült fel egyéb lehetőség (pályázati program kapcsán, munkahelyen kívüli előadás, városi rendezvény, továbbképzés). Közülük $61 \%$ több, mint 10 éve tanulta (65 fő), 27,6\% (30 fő) több, mint 1 éve, de kevesebb, mint 10 éve, míg csupán 11,4\% (12 fő) tanulta az elmúlt egy évben. A kitöltők mintegy fele (49,1\%, 56 fő) került már olyan helyzetbe, ahol elsősegélyt kellett nyújtania, melyben elmondásuk alapján tudtak is cselekedni. A kitöltók töredéke (1,8\%, 2 fő) nyilatkozott úgy, hogy ilyen helyzetben nem tudott cselekedni. A saját tapasztalatok szerint a válaszadók egynegyede (25,4\%, 29 fő) arról számolt be, hogy nem volt még olyan eset a munkahelyén, hogy gyerekek észleltek balesetet, rosszullétet. Akik tapasztaltak ilyet, 60,5\%-uk (51 fó) esetében a gyerekek rögtön szóltak egy felnőttnek, de nem kezdték meg a segítségnyújtást, 25,5\% (22 fö) esetében nem kezdtek elsősegélynyújtást és nem is szóltak pedagógusnak (aki így később észlelte csak a helyzetet), viszont 14\% (12 fó) esetében a gyerekek kezdték meg az elsősegélynyújtást, majd ezzel párhuzamosan szóltak felnőttnek.

1. táblázat: A kitöltők föbb szocio-demográfiai adatai, valamint korábbi elsősegélynyújtással kapcsolatos jellemzői a beosztás és az iskola típusa szerinti bontásban ( $N=114)$

\begin{tabular}{|c|c|c|c|c|c|c|}
\hline & & \multicolumn{2}{|c|}{ Pedagógus } & \multicolumn{2}{|c|}{ Intézmény vezetője } & \multirow[b]{2}{*}{ Összesített } \\
\hline & & $\begin{array}{l}\text { Általános } \\
\text { iskola }\end{array}$ & Középiskola & $\begin{array}{l}\text { Általános } \\
\text { iskola }\end{array}$ & Középiskola & \\
\hline \multirow{2}{*}{ Nem } & Férfi & $14,7(10)$ & $23,1(3)$ & $25,9(7)$ & $50(3)$ & 20,2 (23) \\
\hline & Nő & $85,3(58)$ & 76,9 (10) & $74,1(20)$ & $50(3)$ & $79,8(91)$ \\
\hline Életkor (év) & & $49,7 \pm 9,36$ & $47,23 \pm 7,61$ & $55,74 \pm 5,97$ & $57,1 \pm 3,66$ & $51,25 \pm 8,7$ \\
\hline $\begin{array}{l}\text { Munkában eltöltött idő } \\
\text { (év) }\end{array}$ & & $24,69 \pm 11,59$ & $21,92 \pm 9,37$ & $33,67 \pm 5,65$ & $33,67 \pm 4,18$ & $26,97 \pm 10,78$ \\
\hline \multirow{2}{*}{$\begin{array}{l}\text { Tanult korábban } \\
\text { elsősegélynyújtást? }\end{array}$} & Igen & $94,1(64)$ & $92,3(12)$ & $92,6(25)$ & $100(6)$ & 93,9 (107) \\
\hline & Nem & $5,9(4)$ & $7,7(1)$ & $7,4(2)$ & $0(0)$ & $6,1(7)$ \\
\hline \multirow{2}{*}{$\begin{array}{l}\text { Kellett korábban } \\
\text { elsősegélyt nyújtania? }\end{array}$} & Igen & $51,5(35)$ & $53,9(7)$ & $55,6(15)$ & $16,7(1)$ & $49,1(56)$ \\
\hline & Nem & $48,5(33)$ & $46,1(6)$ & $44,4(12)$ & $83,3(5)$ & $50,9(58)$ \\
\hline \multirow{3}{*}{$\begin{array}{l}\text { Elsősegélynyújtás } \\
\text { része a NAT-nak? }\end{array}$} & Igen & $32,4(22)$ & $23,1(3)$ & 33,3 (9) & $50(3)$ & $32,5(37)$ \\
\hline & Nem & $36,8(25)$ & $69,2(9)$ & $59,3(16)$ & $33,3(2)$ & $45,6(52)$ \\
\hline & $\begin{array}{l}\text { Nem } \\
\text { tudja }\end{array}$ & $30,8(21)$ & $7,7(1)$ & $7,4(2)$ & $16,7(1)$ & $21,9(25)$ \\
\hline
\end{tabular}

Forrás: saját szerkesztés 
Majdnem minden kitöltő (98,2\%, 112 fő) arról számolt be, hogy van elsősegély-doboz az iskolájukban, a többiek a „nem tudom” választ adták. $A z$ iskolák 6,1\%-ában (7 db) érhető el félautomata defibrillátor. Az eszközök esetleges használatával kapcsolatban azt a választ kaptuk, hogy az iskolák 44,7\%-ában (19 db) van elsősegélynyújtásra kijelölt személy, 40,4\%-ban (17 db) van olyan pedagógus, aki tudja ezeket használni, 3,5\% (2 db) esetében minden pedagógus képes ezeket használni, míg 11,1\%-ban (5 db) nincs ilyen személy.

Az intézmények vezetőinek válaszai alapján a felmérésben résztvevő intézményekbe összesen 9856 gyermek járt (általános iskolába 6761 fő, középiskolába 3095 fő) a megkérdezés időpontjában.

Mindössze a kitöltők harmada (32,5\%, 37 fő) volt vele tisztában, hogy a NAT-nak részét képezi az elsősegélynyújtás oktatása, 45,6\% (52 fő) szerint nem része, míg 21,9\% (25 fő) úgy nyilatkozott, hogy nem tudja.
A gyermekkorban elkezdett elsősegélynyújtás oktatással kapcsolatos attitűd

A kitöltők fontosnak tartják a gyermekkorban elkez-

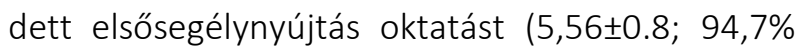
„inkább egyetért” (4-6) választ adott). A válaszadók 63,2\%-a (72 fő) szerint az elsősegélynyújtásnak kötelező részét kellene képeznie a tantervnek, 35,1\% (40 fő) fontosnak tartaná, de szabadon választható témaként és mindössze 1,8\% (2 fö) válaszolt úgy, hogy nem tartja indokoltnak. A kérdőívünk bevezetőjében feltüntetett rövid tájékoztató alapján a kitöltők 93\%-a (106 fő) egyetért a „Kids Save Lives" program hasznosságával és szükségességével.

A kitöltők többségének fontos lenne, hogy a gyerekek tudjanak elsősegélyt nyújtani (96,5\% „inkább egyetért" (4-6) választ adott), tanuljanak elsősegélynyújtást a köznevelés keretein belül (93,9\% „ „inkább egyetért” (4-6) választ adott), hosszú távon növekedjen a helyes beavatkozások száma (96,5\% „inkább egyetért” (4-6) választ adott). A kitöltők további válaszai a 2. táblázatban láthatók.

2. táblázat: A kitöltők véleménye a köznevelés keretein belül megvalósuló elsősegélynyújtás oktatás fontosságáról ( $N=114)$

\begin{tabular}{|lccccc|}
\hline \multicolumn{1}{|c}{ Kérdés } & \multicolumn{2}{c}{ Pedagógusok } & \multicolumn{2}{c|}{ Intézmények vezetői } & \\
& $\begin{array}{c}\text { Általános } \\
\text { iskola }\end{array}$ & Középiskola & $\begin{array}{c}\text { Altalános } \\
\text { iskola }\end{array}$ & Középiskola & Összesen \\
\hline $\begin{array}{l}\text { Fontos, hogy a gyerekek } \\
\text { tudjanak elsősegélyt nyújtani? }\end{array}$ & $5,41 \pm 0,92$ & $5,69 \pm 0,63$ & $5,48 \pm 0,8$ & $5,33 \pm 0,52$ & $5,46 \pm 0,84$ \\
\hline $\begin{array}{l}\text { Elsősegélynyújtás fontossága } \\
\text { a köznevelés keretein belül? }\end{array}$ & $5,25 \pm 0,97$ & $5,69 \pm 0,63$ & $5,44 \pm 1,01$ & $4,67 \pm 1,21$ & $5,32 \pm 0,97$ \\
\hline $\begin{array}{l}\text { Fontos, hogy hosszú távon } \\
\text { javuljon a segítségnyújtási } \\
\text { hajlandóság? }\end{array}$ & $5,62 \pm 0,62$ & $5,38 \pm 1,19$ & $5,48 \pm 0,89$ & $5,17 \pm 0,75$ & $5,54 \pm 0,78$ \\
\hline
\end{tabular}

Forrás: saját szerkesztés

A válaszok 6 fokozatú Likert-skálán kerültek felmérésre ( $1=$ „egyáltalán nem értek egyet”, $6=$ ",teljes mértékben egyetértek"). Az átlagok után a szórás értéke is feltüntetésre került.

A résztvevőket megkértük, hogy az elsősegélynyújtás oktatásának fontossága tekintetében próbálják megválaszolni a kérdést a gyerekek $(4,08 \pm 1.05$; 68,4\% „inkább egyetért” (4-6) válaszok) és a

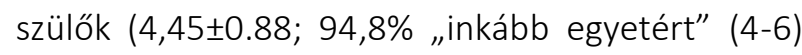

válaszok), valamint más pedagógusok $(5,05 \pm 0,92$; $94,8 \%$ „inkább egyetért” (4-6) válaszok) és az intézmények vezetői $(5,25 \pm 1,05 ; 68,4 \%$ „inkább egyetért" (4-6) válaszok) szemszögéből is.

A megkérdezettek 8,8\%-a (10 fó) szerint a gyerekek nem lennének képesek a megszerzett ismereteket és készségeket a valóságban használni. Akik szerint igen, feltételhez kötötték: a válaszadók 56,1\%-a (58 fő) szerint személyiség és életkor függvénye, míg 35,1\%-a (37 fő) szerint akkor tudnának 
cselekedni, ha korábban már tanultak az elsősegélynyújtásról. Egy válaszadó sem gondolta, hogy korábbi elsősegélynyújtás oktatás nélkül is képesek lehetnek a gyerekek segítségnyújtásra.

A résztvevők 60,6\%-a (69 fő) tartana elsősegélynyújtással kapcsolatos programot, míg 39,4\%-uk (45 fő) nem tartana. A válaszadók közül 7\% (8 fő) jelenleg is ellát ilyen jellegű tevékenységet. A kitöltők között vannak, akik ellátnák ezt a feladatot, de csak egy ezirányú képzést követően. A „nem” választ adók közül többen okként azt adták meg, hogy nem tartanák magukat hitelesnek, vagy nincs rá idejük, illetve nem rendelkeznek a megfelelő ismeretekkel saját meglátásuk szerint.
A gyermekek elsősegélynyújtással kapcsolatos ismereteinek szinten tartása kapcsán 1,8\% (2 fő) gondolta úgy, hogy nincs szükség ismétlésre az iskolai keretek között, 97,3\% (111 fő) szerint viszont fontos az ismétlés a szinten tartás miatt, valamint azért, mert bizonyos időközönként változhat az ellátás módszere. A kitöltők 0,9\%-a (1 fő) szerint egyáltalán nem fontos az elsősegélynyújtás oktatása, mert kevés olyan valós helyzet fordul elő, ahol valóban szükség lenne a segítségnyújtásra.

Az összefüggések vizsgálatával kapcsolatos eredményeink a 3. táblázatban tekinthetők meg.

3. táblázat: A szocio-demográfiai- és korábbi elsősegélynyújtással való kapcsolat összefüggései a kérdésekre adott válaszokkal $(N=114)$

\begin{tabular}{|c|c|c|c|c|c|c|c|}
\hline $\begin{array}{l}\text { KÉRDÉS / VIZSGÁLT } \\
\text { VÁLTOZÓ }\end{array}$ & Nem & Életkor & $\begin{array}{l}\text { Iskola } \\
\text { típusa }\end{array}$ & Beosztás & $\begin{array}{l}\text { Munkában } \\
\text { eltöltött } \\
\text { évek }\end{array}$ & $\begin{array}{l}\text { Korábban tanult-e } \\
\text { elsősegélynyúj- } \\
\text { tást? }\end{array}$ & $\begin{array}{l}\text { Került-e már első- } \\
\text { segélynyújtást } \\
\text { igénylő } \\
\text { szituációba? }\end{array}$ \\
\hline $\begin{array}{l}\text { Fontosnak tartja a gyermekkor- } \\
\text { ban elkezdett elsősegélynyúj- } \\
\text { tás oktatást? }\end{array}$ & 0,806 & 0,566 & 0,224 & 0,883 & 0,063 & 0,821 & 0,550 \\
\hline $\begin{array}{l}\text { Kötelezővé tenné-e az } \\
\text { elsősegélynyújtás oktatást } \\
\text { a köznevelésen belül? }\end{array}$ & 0,757 & 0,601 & 0,811 & 0,055 & 0,087 & 0,872 & 0,459 \\
\hline $\begin{array}{l}\text { Egyetért a „Kids Save Lives,, } \\
\text { elveivel? }\end{array}$ & 0,559 & 0,182 & 0,185 & 0,562 & 0,990 & 0,449 & 0,674 \\
\hline $\begin{array}{l}\text { Fontos, hogy a gyerekek tudja- } \\
\text { nak elsősegélyt nyújtani? }\end{array}$ & 0,130 & 0,937 & 0,857 & 0,821 & 0,256 & 0,915 & 0,826 \\
\hline $\begin{array}{l}\text { Elsősegélynyújtás fontossága a } \\
\text { közoktatás keretein belül? }\end{array}$ & 0,250 & 0,518 & 0,848 & 0,863 & 0,580 & 0,793 & 0,841 \\
\hline $\begin{array}{l}\text { Fontos, hogy hosszú távon ja- } \\
\text { vuljon a segítségnyújtási haj- } \\
\text { landóság? }\end{array}$ & 0,287 & 0,779 & 0,100 & 0,560 & 0,783 & 0,836 & 0,660 \\
\hline $\begin{array}{l}\text { Képesek a gyerekek használni a } \\
\text { megszerzett } \\
\text { ismereteket? }\end{array}$ & 0,864 & 0,215 & 0,220 & 0,290 & 0,871 & 0,107 & 0,467 \\
\hline Oktatna elsősegélynyújtást? & 0,134 & 0,780 & 0,390 & 0,166 & 0,419 & 0,298 & 0,346 \\
\hline $\begin{array}{l}\text { Fontosnak tartja az ismeretek } \\
\text { rendszeres frissítését? }\end{array}$ & 0,127 & 0,087 & 0,405 & 0,680 & 0,613 & 0,864 & 0,907 \\
\hline
\end{tabular}

Forrás: saját szerkesztés

A táblázat celláiban a matematikai statisztikai elemzés során eredményül kapott p-értékek kerültek feltüntetésre. Két kategorikus változó közötti összefüggést Khi-négyzet-próbával vizsgáltunk (szükség esetén Fishers's exact-teszttel), kategorikus és folytonos változókat t-próbával és ANOVA- 
val hasonlítottunk össze, valamint két folytonos változó közötti összefüggést korreláció-analízissel vizsgáltuk.

Ahogy a 3. táblázatból kiderül, a különböző kérdésekre adott válaszokat egyik vizsgált változó (nem, életkor, az iskola típusa, beosztás, munkában eltöltött évek, korábbi elsősegélynyújtás tanulás ténye, korábbi elsősegélynyújtást igénylő szituációban való részvétel) sem befolyásolta szignifikánsan.

Az intézményekben jelenleg megvalósuló elsősegélynyújtással kapcsolatos programok jellemzői

Az intézmények mindössze 12,3\%-ában ( $5 \mathrm{db}$ ) zajlik rendszeresen elsősegélynyújtás oktatás, 55,3\%ában (24 db) alkalomszerűen, míg a fennmaradó 32,4\%-ában (14 db) nincs ilyen irányú kezdeményezés. Az elsősegélynyújtást oktató intézmények közel háromnegyedében $(72,7 \%, 21 \mathrm{db})$ nincs egységes tematika, mindig az adott oktatóra van bízva a tartalom. Az esetek 53,5\%-ában (23 db) szabadon választható foglalkozásokról van szó, míg a többi esetben kötelező.

$\mathrm{Az}$ intézmények majdnem felében $(42,9 \%, 18 \mathrm{db})$ nincs olyan személy, aki az elsősegélynyújtási programok koordinálását végzi. Ahol van ilyen személy, nagyjából egyenlő arányban oszlanak el a következő lehetőségek: ő a kizárólagos oktató is $(15,6 \%, 4$ db), más kollégákkal együtt vesz részt az oktatásban $(20,8 \%, 5 \mathrm{db})$, vagy csak a szervezést végzi $(20,8 \%$, $5 \mathrm{db})$.

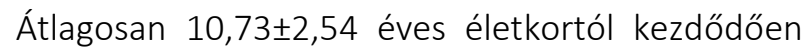
valósulnak meg az elsősegélynyújtással kapcsolatos programok. A legfiatalabb megadott életkor 6 év, míg a legidősebb 17 év volt a kezdésre. Az általános iskolai kitöltők válaszai alapján 9,94₫2,09 éves, míg a középiskolai kitöltók válaszai alapján 15,85ะ1,57 éves életkorban jelennek meg az elsősegélynyújtással kapcsolatos programok először az intézményekben.

Az intézmények több, mint felében $(55,4 \%, 24 \mathrm{db})$ a program egészségnaphoz kapcsolódik, a másik két fő lehetőség a tanóra $(17,6 \%, 8 \mathrm{db})$, vagy a szakkör (13,5\%, 6 db) keretein belül történő megvalósítás.

$\mathrm{Az}$ esetek legnagyobb részében az iskola védőnője $(43,9 \%)$, vagy külső szakember $(40,4 \%)$ tartja a programokat, ennek töredéke csupán, mikor az iskola saját pedagógusa $(20,1 \%)$. Itt a válaszadók több választ is megjelölhettek, hiszen előfordulhat, hogy az adott iskolában a különböző alkalmakkor változik az oktató személye. A programot tartó személyek tekintetében a kitöltők 86,8\%-a (99 fö) úgy gondolta, hogy az lenne a megfelelő megoldás, ha az elsősegélynyújtás oktatásban járatos személyek kapnának pedagógiai támogatást, míg csak kisebb részük (13,2\%; 15 fô) gondolta úgy, hogy a pedagógusok elsősegélynyújtási ismereteinek növelése lenne a megoldás. A kitöltők körülbelül kétharmada szerint (62,3\%, 71 fő) a gyerekek az oktatás után képesek lennének kortárs oktatóként az ismeretek továbbadására. A pedagógusok 71,9\%-a (82 fő) szerint a kortárs oktatás megfelelő módszer, közülük többen úgy vélekednek, hogy a gyerekek nemcsak a társaiknak, hanem családtagjaiknak is közvetíthetik ezeket az ismereteket (38,6\%, 44 fö).

A válaszok alapján az intézmények 69,7\%-ában (29 db) évente ismétlődik a program, a többi esetben ennél ritkábban.

A programokon előkerülő témák változatos képet mutatnak, ezt a 4. táblázatban foglaltuk össze.

4. táblázat: Az elsősegélynyújtással kapcsolatos oktatási programok esetén ténylegesen megjelenő és elvárt témakörök a kitöltók válaszai alapján $(N=114)$

\begin{tabular}{|lcc|}
\hline Témakör & Megvalósult tartalom (\%) & Elvárt tartalom (\%) \\
\hline Mentőhívás & $83,8(1)$. & $98,2(1)$. \\
\hline Újraélesztés & $70,3(4)$. & $71,9(4)$. \\
\hline Vérzéscsillapítás & $77(3)$. & $91,2(2)$. \\
\hline Sebellátás & $79,7(2)$. & $82,5(3)$. \\
\hline Eszméletlen beteg ellátása & $60,8(5)$. & $67,5(5)$. \\
\hline Törések ellátása & $50(6)$. & $49,1(7)$. \\
\hline Légúti idegentest & $33,8(7)$. & $58,8(6)$. \\
\hline Belgyógyászati eredetű rosszullétek & $14,9(8)$. & $33,3(8)$. \\
\hline
\end{tabular}

Forrás: saját szerkesztés 
Zárójelben az adott témakör fontossági sorrendben elfoglalt helye került feltüntetésre a kapott válaszok alapján.

A 4. táblázatban bemutatott eredmények alapján összességében látható, hogy szinte minden témakör megjelenése nagyobb arányban lenne elvárt a pedagógusok által, mint ahogy az valójában megjelenik. A legtöbben a mentőhívás, a vérzéscsillapítás és a sebellátás elsajátítását látnák indokoltnak, ezt követi az újraélesztés témaköre. A ténylegesen megvalósuló programok alkalmával is ezek a leggyakoribb témakörök. Legkevésbé a belgyógyászati jellegú rosszullétekkel kapcsolatos ismeretek elsajátítását tartották fontosnak a pedagógusok.

A köznevelés keretein belül megvalósuló elsősegélynyújtás oktatás lehetséges pozitív hatásaival kapcsolatos véleményeket az 5 . táblázat mutatja be.

5. táblázat: A köznevelés keretein belül megvalósuló elsősegélynyújtás oktatás lehetséges pozitív hatásai a kitöltők szerint ( $N=114)$

\begin{tabular}{|ll|}
\hline Kérdés & Átlagos pontszám \\
\hline Növeli valós helyzetekben a megkezdett elsősegélynyújtás valószínüségét? & $5,22 \pm 0,81$ \\
\hline Csökkenti a félelmet valós elsősegélynyújtást igénylő helyzetekben? & $5,22 \pm 0,86$ \\
\hline Növeli a segítségnyújtás hajlandóságot? & $5,18 \pm 0,85$ \\
\hline Növeli a társadalmi felelősségvállalásból kivett szerepet? & $5 \pm 1,01$ \\
\hline Növeli az embertársakra való figyelés mértékét? & $5,01 \pm 0,96$ \\
\hline Növeli az elsősegélynyújtást igénylő helyzetekben a cselekedni képes laikusok számát? & $5,04 \pm 0,94$ \\
\hline
\end{tabular}

Forrás: saját szerkesztés

A válaszok megadása egy 6 fokozatú Likert-skálán történt ( 1 = „egyáltalán nem értek egyet”, 6 = „teljes mértékben egyetértek”). Az átlagok után a szórás értéke is feltüntetésre került.

Az 5. táblázatban feltüntetett eredményekből látszik, hogy a kitöltők pozitív hatásokat várnának a köznevelés keretein belül megvalósuló elsősegélynyújtás oktatástól. A résztvevők úgy gondolták, hogy az elsősegélynyújtás oktatás növeli a valós helyzetekben megkezdett segítségnyújtás valószínűségét, valamint ennek szakszerűségét, csökkenti az ellátók félelmét, növeli a segítségnyújtási hajlandóságot, valamint globálisabban tekintve növeli a társadalmi felelősségvállalásból kivett szerepet, az egymásra figyelés mértékét, valamint a cselekedni képes laikusok számát.

Összességében a pedagógusok 31,6\%-a (36 fő) szerint a gyerekek élvezik ezeket a foglalkozásokat és fel is fogják a jelentőségét, további 40,4\%-a (46 fö) egyetértett vele, hogy élvezik, de szerintük inkább játéknak fogják fel, 19,3\%-a (22 fő) szerint elfogadják, de különösebben nem foglalkoztatja őket a témakör, míg 8,8\%-a (10 fő) a „nem tudom” választ adta a kérdésre. Ugyanezeket az eredményeket áttekintve, leszúkítve azon intézményekre, ahol korábban megvalósult már elsősegélynyújtás oktatás, a pedagógusok 18,9\%-a (7 fö) szerint a gyerekek élvezik a foglalkozásokat és fel is fogják ezek jelentőségét. Ezen túl további 51,4\% (19 fő) gondolta az elsősegélynyújtás oktatását a gyerekek szempontjából élvezetesnek, ugyanakkor inkább játéknak, melynek lényegét nem képesek felfogni. A kitöltők 16,2\%-a (6 fö) szerint a gyerekek elfogadják az oktatást, de nem különösebben foglalkoztatja őket a téma, míg a fennmaradó 13,5\% (5 fő) a „nem tudom" választ adta.

Az elsősegélynyújtással kapcsolatos oktatási tevékenység előmozdító és gátló tényezőivel kapcsolatos vélemények a 6 . táblázatban láthatók.

A válaszok megadása egy 6 fokozatú Likert-skálán történt ( 1 = „egyáltalán nem értek egyet”, 6 = „, teljes mértékben egyetértek"). Az átlagok után a szórás értékének feltüntetése is megtörtént.

A 6. táblázatban megnevezett, az iskolai elsősegélynyújtás oktatást elősegítő tényezők közül a kitöltők a pedagógusok elhivatottságát és az egészségügyi dolgozókkal történő kapcsolattartást jelölték meg a legfontosabbként. Ettől némileg elmaradtak a pályázati lehetőségek és támogatások, valamint a pedagógusok utolsóként jelölték a társadalmi 
nyomást, mint elősegítő tényezőt. A gátló tényezők tekintetében legjelentősebbnek a megfelelő személy jelenlétének hiányát, valamint az időhiányt jelölték a kitöltők. További jelentős korlátként került megnevezésre a szükséges eszközök hiánya, valamint ezek karbantartásának nehézségei és a megfelelő egységes szabályozás hiánya. Ezekhez képest a pedagógusok kevésbé tartották jelentős gátló tényezőnek, hogy vannak, akik szükségtelennek tartják gyermekkorban, valamint, hogy esetlegesen ijesztő lehet a gyermekeknek.

6. táblázat: A köznevelés keretein belül megvalósuló elsősegélynyújtással kapcsolatos nevelés-oktatás elösegitő és gátló tényezői a kitöltők válaszai alapján ( $N=114)$

\begin{tabular}{|c|c|c|}
\hline & & Átlagos pontszám \\
\hline \multirow{5}{*}{ Elősegítő tényezők: } & Pedagógusok elhivatottsága a téma iránt & $5,32 \pm 0,79$ \\
\hline & Kapcsolattartás egészségügyi szakemberekkel & $5,18 \pm 0,86$ \\
\hline & $\begin{array}{l}\text { Pályázati lehetőségek elsősegélynyújtással kapcsolatos } \\
\text { programokra, eszközökre }\end{array}$ & $4,82 \pm 1,05$ \\
\hline & Társadalmi nyomás & $3,85 \pm 1,1$ \\
\hline & Önkormányzati, vagy egyéb támogatások & $4,01 \pm 1,52$ \\
\hline \multirow{8}{*}{ Gátló tényezők: } & Nincs az intézményben megfelelö személy, aki megtartaná & $4,95 \pm 1,13$ \\
\hline & Nincs rá elegendő idő & $4,82 \pm 1,321$ \\
\hline & Nem illeszthetö be a tantervbe & $3,63 \pm 1,47$ \\
\hline & Nem állnak rendelkezésre megfelelö eszközök & $4,3 \pm 1,45$ \\
\hline & Eszközök karbantartásának nehézsége & $4,4 \pm 1,46$ \\
\hline & Gyermekkorban szükségtelen & $3,51 \pm 1,43$ \\
\hline & ljesztően hathat a gyermekekre & $3,4 \pm 1,28$ \\
\hline & Nincs megfelelö, egységes szabályozás a kivitelezésre & $4,04 \pm 1,37$ \\
\hline
\end{tabular}

Forrás: saját szerkesztés

Az iskolai elsősegélynyújtás programokkal kapcsolatos általános vélemények

A kitöltők válaszai alapján 9,93×2,34 éves életkor lenne alkalmas (általános iskolai kitöltők: 9,72ะ2,31

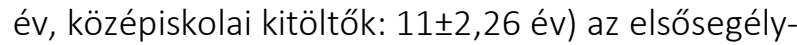
nyújtással kapcsolatos ismeretek átadásának elkezdésére. A téma oktatását mindössze a kitöltők 1,8\%-a (2 fő) nem tartja szükségesnek. Akik szükségesnek tartanák, 50,9\%-a (58 fö) szerint mindenkinek kötelezően tanulnia kellene tanóra keretein belül, 7,9\%-a (9 fö) szerint kötelezőnek kellene lennie, de tanóra keretein kívül, míg 39,5\%-a (45 fő) szerint szabadon választhatóként kellene megjelennie.

Az oktató személyére vonatkozó kérdés esetében több válasz is megjelölhető volt: a válaszadók 74,6\%-a (85 fő) szerint külső szakembernek (pl. mentőtiszt, orvos), 50,9\%-a (58 fő) szerint elsősegélynyújtás oktatásban jártas pedagógusnak, 48,2\%-a (55 fő) szerint az iskola védőnőjének kellene az oktatást végezni, míg 5,3\%-a (6 fö) gondolja úgy, hogy elsősegélynyújtás oktatásban nem járatos pedagógus is végezhetné.

A válaszadók fele szerint (50,9\%, 58 fó) évente kellene ismétlő képzést tartani, sőt további 38,6\% (44 fő) szerint évente többször lenne szükség erre. Rajtuk kívül a pedagógusok 4,4\%-a (5 fö) kétévente, 2,6\%-a (3 fő) ritkábban, mint kétévente tartaná indokoltnak az ismétlést, míg 3,5\% (4 fö) szerint összesen elég lenne egyszer ezzel foglalkozni.

Az elsajátítandó témaköröket tekintve a mentőhívás és a legsúlyosabb, leggyorsabb beavatkozást igénylő helyzetek kerültek megjelölésre, melyek a 4. táblázatban láthatók. Az „Egyéb” válaszlehetőség esetén a következő témakörök kerültek még megemlítésre: áramütés, rovarcsípés, mérgező növények, égés, allergia.

A kitöltők 96,5\%-a (110 fő) igényelné, hogy a jövőben legyenek elsősegélynyújtással kapcsolatos programok az intézményükben. 


\section{MEGBESZÉLÉS}

Jelen kutatásunk fő erőssége, hogy részletesen vizsgálta a gyermekkorban elkezdett elsősegélynyújtás oktatással kapcsolatos jelenlegi helyzetet és az ezzel kapcsolatos véleményeket a Pécsi Tankerületi Központ általános- és középiskoláiban egyaránt.

A gyermekkorban elkezdett elsősegélynyújtás oktatás hatékonyságát korábban több kutatás bizonyította, melyek nyomán ezzel kapcsolatos állásfoglalások is születtek. ${ }^{7,8,11} \mathrm{~A}$ legnagyobb hatékonyságot akkor érhetnénk el, ha az elsősegélynyújtás kötelező és egységes módon kerülne bevezetésre a köznevelésbe. ${ }^{10}$ Ezért is tartottuk fontosnak, hogy megszólítsuk a köznevelési intézmények képviselőit, hiszen nélkülük ebben a vonatkozásban nem érhetünk el eredményeket. Vizsgálatunk résztvevői a Pécsi Tankerületi Központ intézményeinek vezetői és pedagógusai voltak. A kutatás során 114 résztvevőtől kaptunk választ, összesen 43 intézményből. A résztvevők közül majdnem mindenki tanult korábban valamilyen formában elsősegélynyújtást, viszont a legtöbben ezt több mint 10 éve tették. A megszerzett ismereteket körülbelül a válaszadók felének már kellett is alkalmaznia a való életben.

A megkérdezett pedagógusok válaszaik alapján fontosnak tartják a gyerekek elsősegély oktatását, ennek számos pozitívumát említették. Körülbelül a résztvevők kétharmada kötelezővé tenné az elsősegélynyújtás oktatását, melyet követően nagy részük képesnek is tartaná a gyerekeket, hogy a megszerzett ismereteiket és készségeiket használják a való életben.

Az iskolai keretek között megvalósuló elsősegélynyújtás oktatás kapcsán megemlítendő, hogy a világon több országban az újraélesztés a tanterv kötelező részét képezi. ${ }^{8,25}$ Hazánkban a NAT-nak 1995 óta részét képezi az elsősegélynyújtás. ${ }^{13}$ Sajnálatos módon, ezt a tényt csupán a kitöltők egyharmada tudta, ami egy korlátja lehet a széles körú bevezetésnek, hiszen ha az érintettek nincsenek tisztában ennek NAT-ban való megjelenésével, nem feltétlen történnek erőfeszítések a megvalósítás érdekében. Ezt erősítik az előzőekben bemutatott eredményeink, melyekből kiderült, hogy a pedagógusok fontosnak tartanák az elsősegélynyújtás oktatását és nagy arányban kötelezővé is tennék azt. Egy Dániában elvégzett kutatás adatai alapján a kötelező bevezetés ellenére, 8 év elteltével sem alakult ki az újraélesztés oktatásának egységes rendszere, annak ellenére, hogy a pedagógusok támogatók. ${ }^{19} \mathrm{Ez}$ is mutatja, hogy helyzetünk nem egyedi, hiszen még olyan országokban is problémát jelent, ahol egyébként hosszú évtizedes hagyománya van a gyermekkori elsősegélynyújtás oktatásnak.

Ennek ellenére természetesen vannak elsősegélynyújtással kapcsolatos programok az egyes intézményekben, de ezek egyelőre főként egészségnaphoz, vagy más rendezvényhez kötődnek, a tanterv részeként csupán az intézmények kevesebb, mint 20\%-ában jelenik meg az elsősegélynyújtás. Ebből következik, hogy a felmért intézmények tekintetében nem beszélhetünk egységességről és rendszerességről. Az intézmények több, mint felében évente tartanak elsősegélynyújtással kapcsolatos programot, de általában valamilyen rendezvényhez kapcsoltan. Ez egybevág a nemzetközi adatokkal, melyek ugyancsak azt mutatják, hogy az esetek nagy részében ezen programok valamilyen más rendezvényhez kötődve jelennek meg. ${ }^{23} \mathrm{~A}$ kitöltők véleménye szerint a téma évente történő ismétlése fontos lenne, mely - bár nem egységes formában, de - az intézmények körülbelül felében megvalósul.

A téma bevezetése általánosságban 10-11 éves életkorra tehető, mely megfelel a „Kids Save Lives” ajánlásban foglaltaknak, ennek ellenére úgy gondoljuk, hogy ez az életkor lejjebb mozdítható lenne, mely bizonyos intézményekben meg is történik. ${ }^{7,11,17} \mathrm{Az}$ ismeretek átadásának elkezdése tekintetében az általános iskolai kitöltők a felső tagozat kezdetét, míg a középiskolai kitöltők a középiskola kezdetét tartanák alkalmasnak. Az optimális életkor meghatározása a kezdés tekintetében egyelőre kérdéses. ${ }^{23} \mathrm{~A}$ megvalósult programok témaköreit tekintve változatos képet láthatunk, a kitöltők szerint ez az adott programtól, valamint az oktató személyétől függ. Ezek között általában a leggyakoribb és/vagy legsürgetőbb beavatkozást igénylő helyzetek szerepelnek (pl. újraélesztés, sebellátás, eszméletlen beteg ellátása, vérzéscsillapítás), ezeken kívül pedig a mentőhívás szinte minden esetben helyet kap. Összehasonlítva a megvalósult programok témaköreit az azzal kapcsolatos általános véleményekkel, hogy milyen tartalomnak kellene megjelenni, átfedést láthatunk. Különböző nemzetközi szervezetek az újraélesztés megtanításának fontosságát kiemelt feladatként kezelik, 
ennek ellenére fontosnak tartjuk egyéb témakörök tárgyalását is. ${ }^{711,17}$ Egy norvég felmérésben is saját eredményeinkhez hasonló problémát említettek, miszerint a tantervbe való beemeléssel kapcsolatos szabályozás nem egyértelmű, ezért a programok témakörei szerteágazóak. ${ }^{9}$

$\mathrm{Az}$ eredményeinket a minta szocio-demográfiai jellemzői és az elsősegélynyújtással kapcsolatos előzmények nem befolyásolták.

A gyermekkori elsősegélynyújtás oktatásban fontos szerep jut az oktató személyének. Általános tapasztalat, melyet kutatásunk kitöltői is megerősítettek, hogy hazánkban az esetek nagy részében egészségügyi szakember látja el ezt a feladatot (legtöbb esetben külső szakember, bizonyos esetekben pedig az iskola védőnője). Ahhoz viszont, hogy az ismeretek minél szélesebb körben közvetíthetők legyenek, fontos alternatív megoldásokat is kipróbálni. Ilyen lehet például, ha ezt a feladatot a gyerekek saját pedagógusai látják el, melynek hatékonysága korábban több esetben bizonyítást nyert. ${ }^{26}$ Jelen felmérésünk résztvevőinek körülbelül kétharmad része képesnek érezné magát a feladat ellátására, de közülük sokan csak egy ezirányú képzésen való részvételt követően. Érdekes eredmény, hogy a kitöltők magasabbra értékelték saját hajlandóságukat arra vonatkozóan, hogy szívesen oktatnának-e elsősegélynyújtást, mint általánosságban a pedagógusok közösségét. A pozitívnak tűnő hajlandóság ellenére a megvalósult programokat körülbelül az esetek 20\%-ában tartották meg az iskola saját pedagógusai, valamint a kapott vélemények alapján a kitöltők több, mint háromnegyede külső szakember bevonását javasolná erre a feladatra. Azon kitöltők, akik nem látnák el ez a feladatot, fő indokként az idő hiányát, az ismeretek és a szakértelem hiányát jelölték meg, valamint a tényt, hogy nem éreznék magukat hitelesnek ebben a szerepben. Ezen indokok egybevágnak a szakirodalmi adatokkal. 18,19,20,21,22,23 A résztvevők háromnegyede a saját elsősegélynyújtás témájú képzése helyett az egészségügyi szakemberek pedagógiai irányú képzését látná jobb megoldásnak. A pedagógusok bizonytalansága, illetve az egészségügyi szakemberekbe vetett nagyobb hite a feladat ellátása kapcsán korábbi esetben is megfogalmazásra került. ${ }^{22}$ Egy másik alternatíva lehet a kortárs oktatás, melyben a gyerekek az ismeretek elsajátítása mellett oktatói feladatkört is elláthatnak, továbbadva az ismereteket osztálytársaiknak, kortársaiknak. ${ }^{27,28}$ A kitöltők közel háromnegyede ezt megfelelő módszernek ítélte meg és kicsit több, mint 60\%-uk képesnek is tartaná a gyerekeket erre a feladatra.

A felmérésben a kitöltők számos elősegítő és gátló tényezőt is megneveztek, melyek hasonló eredményeket mutatnak, mint a szakirodalomban. ${ }^{18,19,20,21,22,23}$ Fő elősegítő tényezőként említették a kitöltők a pedagógusok elhivatottságát, valamint a megfelelő kapcsolatrendszert, míg gátló tényezőként megjelent például az időhiány, a megfelelő szabályozás hiánya, valamint a szükséges eszközök rendelkezésre állásának hiánya. Ezek is mutatják, hogy akár a megvalósulást, akár annak hiányát rengeteg tényező befolyásolja, melyek beavatkozást igényelnek. A probléma több oldalról történő megközelítésének igényét azon eredményünk is mutatja, hogy majdnem minden kitöltő igényelné, hogy az intézményében legyen elsősegélynyújtással kapcsolatos oktatás, de ez a kívánt formában csak kevés esetben történik meg ténylegesen.

\section{A kutatás korlátai}

Kutatásunkban a Pécsi Tankerületi Központot vizsgáltuk, mely adatokból nem általánosíthatunk az országos viszonyokra. A teljes kép feltérképezése érdekében tervezzük egy egész országra kiterjedő vizsgálat elvégzését azonos módszertannal. Eredményeink hazai viszonyok között értelmezhetők relevánsan, más országok iskolarendszeréhez nem kapcsolódnak szorosan. Az alacsonyabb kitöltési hajlandóság miatt nem sikerült a Pécsi Tankerületi Központ minden intézményéből adatokat gyűjtenünk, mely tényt szükséges volt az eredmények értelmezésénél figyelembe vennünk. Viszont megemlítendő, hogy azonos témájú nemzetközi vizsgálatokban is hasonló részvételi hajlandóságot sikerült mindössze elérni a bevont intézmények tekintetében. Ezt befolyásolhatta, hogy a kérdőív kitöltése körülbelül 20 percet vett igénybe, így egy rövidebb kérdőívvel esetlegesen növelhető lett volna a kitöltési hajlandóság. Utóbbi esetben viszont számolnunk kellett volna bizonyos mértékú adatvesztéssel is, míg jelen célunk a széleskörű adatfelvétel volt, ezzel indokolható a hosszabb kérdőív. Jelen kérdőivünkben célunk az általános vélemény felmérése volt, így nem gyújtöttünk adatokat arra 
vonatkozóan, hogy melyik pedagógus pontosan mely korosztállyal foglalkozik, valamint milyen tantárgyakat oktat. Ezen tények a kutatás kiterjesztésekor hasznosak lehetnek további elemzések elvégzésére. Egy esetleges későbbi, kvalitatív jellegű kutatás során mélyebben elemezhetővé válhatnának a vizsgált tényezők. Tekintettel kutatásunk feltáró jellegére, jelen fázisban célunk az általános helyzetkép ismertetése volt, nem pedig a mélyebb összefüggések analizálása, így matematikai statisztikai eljárásokat csak limitáltan végeztünk. Az említett mélyebb összefüggések feltárására alkalmas lehet a jövőben a kutatásban résztvevők körének bővítése.

\section{KÖVETKEZTETÉSEK}

Az elsősegélynyújtás társadalmasítása során, a gyermekkorban elkezdett oktatás egységességének elérésében a köznevelési intézményeknek és ezek fenntartóinak fontos szerepük van. A megkérdezett intézmények vezetői és pedagógusai összességében pozitívan állnak az elsősegélynyújtás oktatás bevezetéséhez, nem zárkóznak el a jelenlegi helyzet javításától. Az egységesen megjelenő elsőse- gélynyújtás oktatásával kapcsolatos programok segítségével csak a Pécsi Tankerületi Központ intézményeiben közel 20,000 gyermek lenne elérhető, akik az oktatást követően olyan potenciális felnőttekké válhatnak, akik képesek segíteni egy valós segítségnyújtást igénylő szituációban. Látható, hogy számos esetben jelenleg is megvalósulnak elsősegélynyújtással kapcsolatos programok. Ennek ellenére számos megoldandó probléma is napvilágot látott, melyek megoldása feltétlenül szükséges a cél eléréséhez. Az ehhez szükséges feltételek megteremtése elengedhetetlen a valódi eredmények eléréséhez, mely egyértelműen multiszektorális feladat, minden érintett szervezet együttmúködése egyaránt szükséges.

Köszönetnyilvánítás: A szerzők ezúton szeretnének köszönetet mondani a Pécsi Tankerületi Központ igazgatójának, hogy hozzájárult kutatásunk elvégzéséhez. Ezen kívül köszönet illeti az összes résztvevő intézményvezetőt, valamint a pedagógusokat is, akik a kérdőív kitöltésével hozzájárultak ahhoz, hogy képet kapjunk az elsősegélynyújtás oktatás jelenlegi helyzetéről.

\section{HIVATKOZÁSOK}

\footnotetext{
${ }^{1}$ Tannvik TD, Bakke HK, Wisborg T. A systematic literature review on first aid provided by laypeople to trauma victims. Acta Anaesthesiol Scand. 2012;56:1222-1227. doi: 10.1111/j.1399-6576.2012.02739.x

${ }^{2}$ Gräsner JT, Bossaert L. Epidemiology and management of cardiac arrest: what registries are revealing. Best Pract Res Clin Anaesthesiol. 2013;27:293-306. doi: 10.1016/j.bpa.2013.07.008

${ }^{3}$ Gräsner JT, Lefering R, Koster RW, et al. EuReCa ONE - 27 Nations, ONE Europe, ONE Registry. A prospective one month analysis of out-of-hospital cardiac arrest outcomes in 27 contries in Europe. Resuscitation 2016;105:188-195. doi: 10.1016/j.resuscitation.2016.06.004.

${ }^{4}$ Wissenberg M, Lippert FK, Folke F, et al. Association of national initiatives to improve cardiac arrest management with rates of bystander intervention and patient survival after out-of-hospital cardiac arrest. JAMA 2013;310:1377-1384. doi: 10.1001/jama.2013.278483

${ }^{5}$ Hasselquist-Ax I, Riva G, Herlitz J, et al. Early cardiopulmonary resuscitation in out-of-hospital cardiac arrest. N Engl J Med. 2015;372:2307-2315.doi: 10.1056/NEJMoa1405796 doi: 10.1056/NEJMoa1405796

${ }^{6}$ Diószeghy Cs. A laikus elsősegély szerepe a kórházon kívüli keringésmegállások túlélésében. Orv Hetil. 2019;160:18101815. doi: 10.1556/650.2019.31587

${ }^{7}$ De Buck E, Van Remoortel H, Dieltjens T, et al. Evidence-based educational pathway for the integration of first aid training in school curricula. Resuscitation 2015;94:8-22. doi: 10.1016/j.resuscitation.2015.06.008

${ }^{8}$ Cave DM, Aufderheide TP, Beeson J, et al. Importance and implementation of training in cardiopulmonary resuscitation and automated external defibrillation in schools: a science advisory from the American Hearth Association. Circulation 2011;123:691-706. doi: 10.1161/CIR.0b013e31820b5328.

${ }^{9}$ Bakke HK, Steinvik T, Angell J, et al. A nationwide survey of first aid training and encounters in Norway. BMC Emerg Med. 2017;17:6. doi: 10.1186/s12873-017-0116-7.
} 
${ }^{10}$ Reveruzzi B, Buckley L, Sheehan M. School-based first aid training programs: A systematic review. J Sch Health. 2016;86:266-272. doi: 10.1111/josh.12373.

${ }^{11}$ Böttiger BW, Van Aken H. Kids save lives - Training school children in cardiopulmonary resuscitation worldwide is now endorsed by the World Health Organisation (WHO). Resuscitation 2015;94:A5-A7. doi: 10.1016/j.resuscitation.2015.07.005.

12 Bánfai B, Pandur A, Schiszler B, et al. 'Kids save lives' in Hungary - Implementation, opportunities, programmes, opinions, barriers. Resuscitation 2018;130:e3-e4. doi: 10.1016/j.resuscitation.2018.06.033.

13 130/1995 (X. 26.) Korm. rendelet a Nemzeti Alaptanterv kiadásáról. Letöltve: http://njt.hu/cgi bin/njt doc.cgi?docid=24382.38666 [Elérve: 2020.10 .08 .]

${ }^{14}$ Bánfai B, Pandur A, Pék E, et al. Hány éves kortól képesek a gyermekek újraéleszteni? - A hatékonyság felmérése általános iskolás gyermekek körében. Orv Hetil. 2017;158:147-152. doi: 10.1556/650.2017.30631

${ }^{15}$ Bánfai B, Pandur A, Schiszler B, et al. The (second) year of first aid - a 15-month follow-up after a 3-day first aid programme. Emerg Med J. 2019;36:666-669. doi: 10.1136/emermed-2018-208110.

${ }^{16}$ Letöltve: https://magyarkozlony.hu/dokumentumok/3288b6548a740b9c8daf918a399a0bed1985db0f/megtekintes [Elérve: 2020.08.01.]

${ }^{17}$ Bánfai B, Bánfai-Csonka H, Betlehem J. Hogyan menthetnek életet gyermekeink? Az elsősegélynyújtás oktatásának lehetőségei az iskolában. Új Pedagógiai Szemle 2019;1-2:59-75.

18 Mpotos N, Vekeman E, Monsieurs K, et al. Knowledge and willingness to teach cardiopulmonary resuscitation: A survey amongst 4273 teachers. Resuscitation 2013;84:496-500. doi: 10.1016/j.resuscitation.2013.01.023.

${ }^{19}$ Hansen CM, Zinckernagel L, Ersboll AK, et al. Cardiopulmonary resuscitation training in schools following 8 years of mandating legislation in Denmark: A nationwide survey. J Am Heart Assoc. 2017;6: e004128.

DOI:10.1161/JAHA.116.004128.

${ }^{20}$ Zinckernagel L, Hansen CM, Rod MH, et al. What are the barriers to implementation of cardiopulmonary resuscitation training in secondary schools? A qualitative study. BMJ Open 2016;6:e010481. doi:10.1136/bmjopen-2015-010481.

${ }^{21}$ Salciccioli JD, Marshall DC, Sykes M, et al. Basic life support education in secondary schools: a cross-sectional survey in London, UK. BMJ Open 2017;7:e011436. doi:10.1136/bmjopen-2016-011436.

22 Lockey AS, Barton K, Yoxall H. Opportunities and barriers to cardiopulmonary resuscitation training in English secondary schools. Eur J Emerg Med. 2016;23:381-385. doi: 10.1097/MEJ.0000000000000307.

${ }^{23}$ Zinckernagel L, Hansen CM, Rod MH, et al. A qualitative study to identify barriers to deployment and student training in the use of automated external defibrillators in schools. BMC Emerg Med 2017;17:3. doi: 10.1186/s12873-017-0114-9 ${ }^{24}$ Letöltve: https://kk.gov.hu/kozerdeku-adatok-pecs [Elérve: 2020.08.01.]

${ }^{25}$ Semeraro F, Wingen S, Schroeder DC, et al. KIDS SAVE LIVES - Three years of implementation in Europe. Resuscitation 2018;131:e9-e11. doi: 10.1016/j.resuscitation.2018.08.008.

${ }^{26}$ Böttiger BW, Lockey A, Georgiou M, et al. KIDS SAVE LIVES: ERC Position statement on schoolteachers' education and qualification in resuscitation. Resuscitation 2020;151:87-90. doi: 10.1016/j.resuscitation.2020.04.021

${ }^{27}$ Tóth A, Bánfai-Csonka H, Bánfai B. A kortárs elsősegélynyújtás-oktatás felső tagozatos általános iskolások körében. Magyar Mentésügy 2019;33:8-14.

${ }^{28}$ Fritúz G, Gradvohl E, Feith HJ, et al. Egy lehetséges iskolai „jógyakorlat” az újraélesztés kortársoktatásában. Egy egészségfejlesztési program első tapasztalatai. Orv Hetil. 2019;160:1816-1820. doi: 10.1556/650.2019.31588 